\title{
Targeting protein kinase CK2 suppresses bladder cancer cell survival via the glucose metabolic pathway
}

\author{
Xiaolei Zhang ${ }^{1, *}$, Xiao Yang ${ }^{1, *}$, Chengdi Yang ${ }^{1, *}$, Peng Li $^{1}$, Wenbo Yuan ${ }^{1}$, Xiaheng \\ Deng ${ }^{1}$, Yidong Cheng ${ }^{1}$, Pengchao $\mathrm{Li}^{1}$, Haiwei Yang ${ }^{1}$, Jun Tao ${ }^{1}$, Qiang Lu $^{1}$ \\ ${ }^{1}$ Department of Urology, The First Affiliated Hospital of Nanjing Medical University, Nanjing 210029, China \\ *These authors have contributed equally to this work \\ Correspondence to: Jun Tao, email: Taojun.njmu@139.com \\ Qiang Lu, email: doctorlvqiang@sina.com \\ Keywords: bladder cancer, CK2a, glycolysis, oncogene, prognosis \\ Received: May 14, $2016 \quad$ Accepted: November 7, $2016 \quad$ Published: November 24, 2016
}

\section{ABSTRACT}

Casein kinase 2 (CK2) is a constitutively active serine/threonine kinase that promotes cell proliferation and resists apoptosis. Elevated CK2 expression has been demonstrated in several solid tumors. The expression of CK2a in bladder cancer was elevated in tumor tissues compared with that in adjacent normal tissues. Amplified expression of CK2a was highly correlated with histological grade in bladder cancer(P $=0.024)$. Knockdown of CK2 $a$ in bladder cancer cell lines resulted in a reduction in tumor aerobic glycolysis, accompanied with lower phosphorylated AKT. Moreover, low CK2a levels suppressed cell growth, and similar results could be reproduced after treatment with CX-4945 with a dose-dependent response. CX-4945 inhibited migration and induced apoptosis. Furthermore, knockdown of CK2a decreased the tumorigenicity of bladder cancer cells in vivo. This study is the first to report that CK2 increases glucose metabolism in human bladder cancer. Blocking CK2 function may provide novel diagnostic and potential therapeutic.

\section{INTRODUCTION}

Bladder cancer was the sixth most commonly diagnosed cancer in males in 2012 worldwide and the most common malignancy of the urogenital tract. In 2012, 429,800 new cases of bladder cancer were reported worldwide, meanwhile 165,100 patients died from the disease [1].

Protein kinase casein kinase 2 (CK2) is a conserved, ubiquitously expressed protein serine/threonine kinase that was first discovered by Burnett and Kennedy in 1954 [2]. CK2 exists primarily as a holoenzyme consisting of two catalytic subunits, CK2 $\alpha$ and CK2 2 ', and two $\beta$ regulatory subunits. Functionally, CK2 is involved in the modulation of major cellular processes and pathways $[3,4]$. Subsequent studies have shown that $\mathrm{CK} 2$ was a potent regulator in the processes of cell proliferation, differentiation, and apoptosis, which was involved in numerous signaling pathways including PI3K/AKT, NF-кB, Wnt, Notch1 and Hedgehog/Gli1 [5-9]. Although its pro-survival function is necessary for the whole organism, it is 'more necessary' for cancer cells than normal. Elevated level of CK2 $\alpha$ has been observed in numerous cancers, including breast [10], prostate [11], lung [12, 13], head and neck [14], colorectal [15], gastric [16], and kidney [17]. These evidences validated that $\mathrm{CK} 2$ could be a potential cancer therapeutic target. CX-4945 was the first effective and selective CK2 inhibitor used in human clinical trials. CX4945 inhibits the activity of CK2 $\alpha$ and CK2 2 ', resulted to suppression of activation of pro-survival signaling pathways and promotion of apoptosis in human glioblastoma, breast, prostate, and lung cancers [13, 18-20].

Normal cells metabolize glucose to produce ATP by oxidative phosphorylation and a large amount of pyruvate which is oxidized via the tricarboxylic acid cycle. The rate of production is coupled with oxygen respiration and proton transport [21]. By contrast, tumor cells consume glucose to produce lactate and support mitochondrial oxidative phosphorylation even in oxygen-rich conditions. This phenomenon is referred to as "aerobic glycolysis" or the "Warburg effect" which was first observed in the 1930 s by Otto Warburg [22]. Increased glycolysis is widely considered as a crucial hallmark of cancer, which has been consistently observed in many cancer cell lines [23]. Recent studies indicated that cellular metabolism was directly or indirectly linked to activated oncogenes and 
inactivated cancer suppressors [23, 24]. The expression level of glycolysis-related genes, such as glucose transporter (GLUT)1, lactic dehydrogenase (LDH)A, LDHB, hexokinase (HK)1, HK2, and pyruvate kinase type $\mathrm{M}$ (PKM), are elevated in certain cancer tissues [25], which have been observed in our previous work. Thus, enhanced dependency of cancer cells on glycolysis probably provides a biochemical basis to kill malignant cells preferentially than normal cells by inhibiting glycolysis.

Above all, we reported the function of $\mathrm{CK} 2 \alpha$ in bladder cancer and further investigated the possible relationship between $\mathrm{CK} 2 \alpha$ and glucolysis. We also tested the potential anticancer effect of inhibition of CK2 in vitro and vivo, suggesting its possible application in the treatment of bladder tumors.

\section{RESULTS}

\section{Overexpression of CK2 $\alpha$ in human bladder cancer}

Primary paired $\mathrm{BCa}$ tissue samples and $\mathrm{BCa}$ cell lines were used to examine CK $2 \alpha$ expression. The gene expression of CK $2 \alpha$ was analyzed by qRT-PCR in 22 pairs of BCa tissues and their adjacent tissues. Compared with adjacent bladder tissues, the mRNA level of CK $2 \alpha$ was significantly overexpressed in the bladder tumor tissues $(\mathrm{P}<0.01$; Figure $1 \mathrm{~A}$ and $1 \mathrm{~B})$. To investigate whether differences in expression of mRNA level are reflected at the protein level, Western blot analysis was conducted. Consistent with the PCR results, CK2 $\alpha$ protein expression was significantly higher in the $\mathrm{BCa}$ tissues compared with that in the adjacent tissues (Figure 1C). qRT-PCR analysis demonstrated that mRNA level of CK2 $\alpha$ in six bladder cancer cell lines (T24, J82, EJ, 253J, TCC, and RT4) was increased (particularly in T24) compared with that in the normal urinary epithelial cell line sv-Huc (Figure 1D). Thus, CK $2 \alpha$ expression was positively associated with bladder cancer progression, suggesting that it played an oncogenic role in bladder cancer.

\section{IHC analysis of CK2 $\alpha$ expression in BCa clinical samples}

To further explore the role and prognostic value of CK2 $\alpha$ in human bladder cancer, TMAs with 160 cases of bladder tumor samples were used to examine CK2 $\alpha$ expression via IHC. In the CK2 $\alpha$-positive specimens, high CK2 $\alpha$ expression $(++$ or +++$)$ was found in $101(63.1 \%)$
A

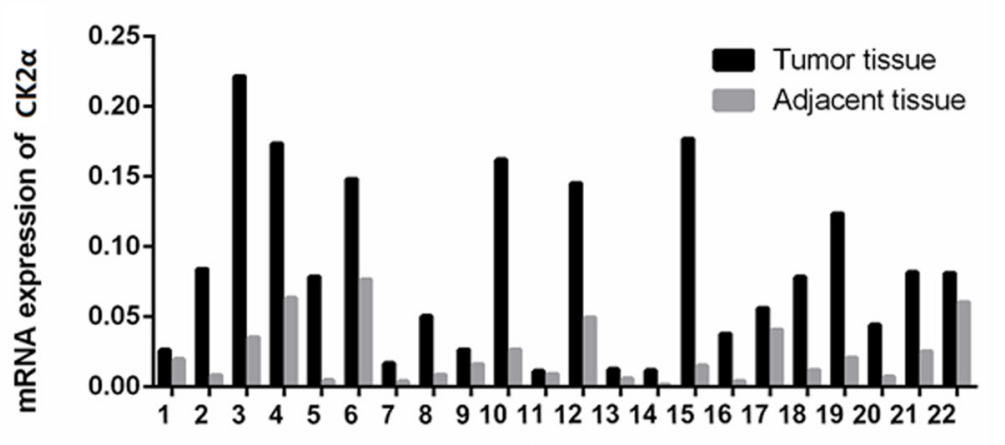

C
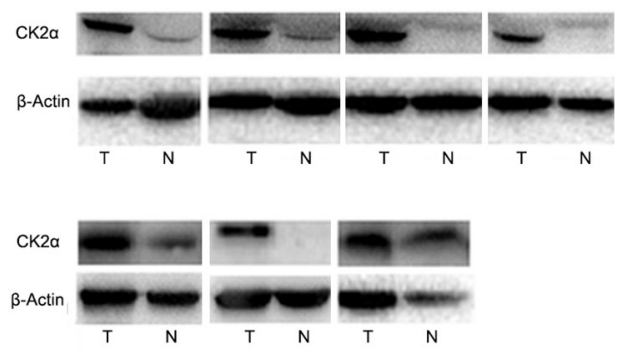

B
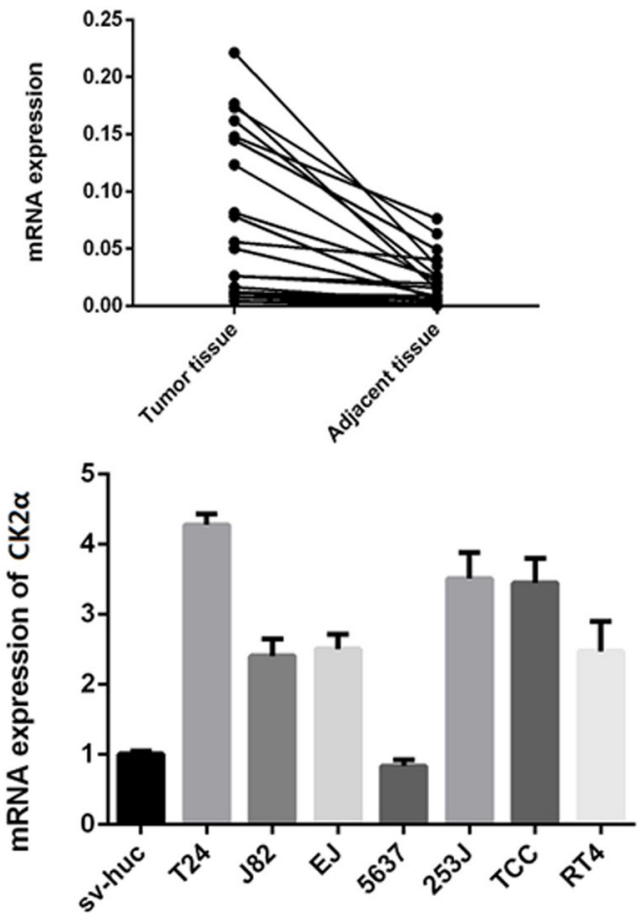

Figure 1: Expression level of CK2 $\alpha$ mRNA and protein in human primary bladder cancer cell lines and surgical specimens as evaluated. A, B. RT-qPCR showed that relative $C K 2 \alpha$ mRNA expression in $22 \mathrm{BCa}$ and adjacent tissues $(P<0.05)$. C. $\mathrm{CK} 2 \alpha$ protein in seven BCa and adjacent tissues (N, non-tumor, $\mathrm{T}$, tumor). D. CK2 $\alpha$ mRNA levels was up-regulated in seven bladder cancer cell lines compared with those in the normal urinary epithelial cell line sv-Huc. 
Table 1: Correlation between CK2 $\alpha$ expression and clinicopathological variables of 160 patients with bladder cancer.

\begin{tabular}{|c|c|c|c|c|}
\hline \multirow{2}{*}{$\begin{array}{l}\text { Clinicopathologic } \\
\text { variable }\end{array}$} & \multicolumn{4}{|c|}{ CK2 $\alpha$ expression } \\
\hline & $\mathbf{N}$ & Low & High & $\mathbf{P}$ \\
\hline All cases & 160 & 59 & 101 & \\
\hline Age(years) & & & & 0.373 \\
\hline$<65$ & 74 & 30 & 44 & \\
\hline$\geq 65$ & 86 & 29 & 57 & \\
\hline Gender & & & & 0.970 \\
\hline Male & 125 & 46 & 79 & \\
\hline Female & 35 & 13 & 22 & \\
\hline TNM stage & & & & 0.308 \\
\hline Stage I & 92 & 37 & 55 & \\
\hline Stage II and III & 68 & 22 & 46 & \\
\hline \multicolumn{5}{|l|}{ Histological grade } \\
\hline grade I and II & 79 & 36 & 43 & 0.024 \\
\hline grade III & 81 & 23 & 58 & \\
\hline Tumor size $(\mathrm{cm})$ & & & & 0.611 \\
\hline$<3$ & 110 & 42 & 68 & \\
\hline$\geq 3$ & 50 & 17 & 33 & \\
\hline
\end{tabular}

${ }^{*} P<0.05$

specimens, and low CK2 $\alpha$ expression $(-$ or + ) was detected in $59(36.9 \%)$ specimens (Table 1$)$. Correlations between the clinicopathological parameters of $\mathrm{BCa}$ and expression of CK2 $\alpha$ are summarized in Table 1 . Chi-square analyses revealed that CK2 $\alpha$ expression was positively correlated with histological grade $(\mathrm{P}=0.024)$ but not with tumor size and tumor stage (TNM). Kaplan-Meier analyses did not reveal a significant association between high CK $2 \alpha$ expression and poor prognosis $(\mathrm{P}=0.694$; Figure $2 \mathrm{~B})$.

\section{CK2 $\alpha$ promotes bladder cancer cell proliferation}

Cell proliferation assay was conducted to explore the role of CK $2 \alpha$ in the growth of bladder cancer cells. T24 and EJ cells were evaluated in cell proliferation assays after they were transiently transfected with $\mathrm{CK} 2 \alpha$-specific siRNAs and siNC RNA (negative control, NC) for $48 \mathrm{~h}$,. Cell proliferation $(\mathrm{P}<0.05$; Figures $3 \mathrm{D}$ and $3 \mathrm{E})$ was significantly inhibited in T24 and EJ cells transiently transfected with siCK $2 \alpha$ compared with those transfected with siNC. These results supported that CK2 $\alpha$ promoted the growth of BCa cells.

\section{Inhibition of CK2 $\alpha$ downregulates the glucose metabolic pathway}

To investigate whether CK2 suppression influences the glucose metabolic pathway, we silenced CK2 $\alpha$ expression. At $48 \mathrm{~h}$ after transfection, the efficiency of RNA interference was monitored by Western blot and qRT-PCR. The corresponding expression of CK2 $\alpha$ in T2 4 and EJ cell lines was decreased (Figures 3A, 3B, and 3C). Glucose uptake and lactate secretion in bladder cancer cells decreased when CK2 $\alpha$ was inhibited (Figures 4A and $4 \mathrm{~B})$. AKT was found to be less phosphorylated at Ser473 in CK2 $\alpha$-silenced cells than in control cells (Figure 4C). AKT is considered the Warburg kinase. PI3K/ AKT/mTOR signaling links several tumor cell metabolic processes, including glycolysis. As such, we found that the protein level of glycolysis-related genes, including GLUT1, G6PD, LDHA, LDHB, HK1, HK2, and PKM, was lower in $\mathrm{CK} 2 \alpha$-silenced cells compared with those in control cells (Figure 4C). Furthermore, treatment with CX-4945 suppressed glucose uptake and lactate secretion (Figures 5F and 5G) in bladder cancer cells. AKT was less phosphorylated at Ser473, and the protein level of glycolysis-related genes was lower in cells after treatment with CX4945 (Figures 5C and 5E). Taken together, CK2 $\alpha$ inhibition may suppress high glycolysis levels via suppressing AKT phosphorylation in bladder cancer cells.

\section{Effects of inhibition of CK2 on BCa cell function}

Treatment with CX-4945 suppressed bladder cancer cell growth in a dose-dependent manner (Figures 5A and 

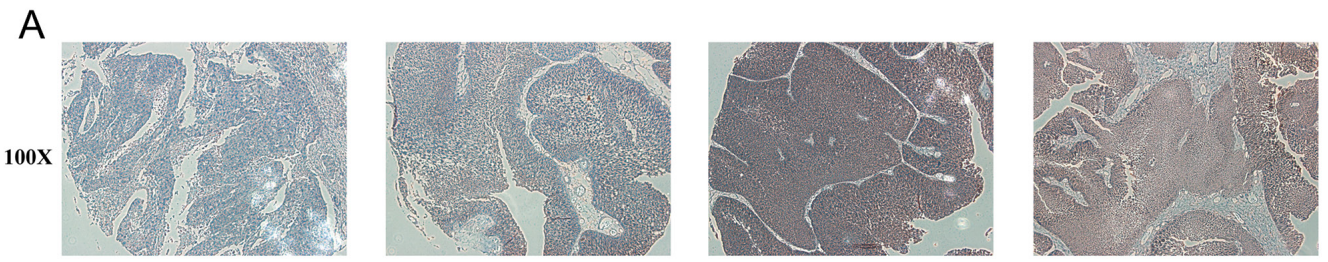

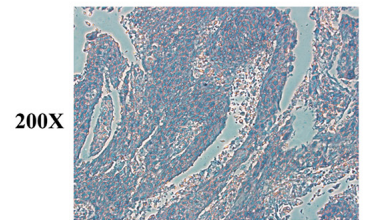

$(-)$

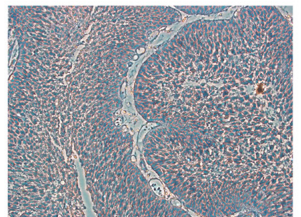

$(+)$

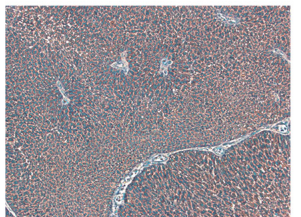

$(++)$

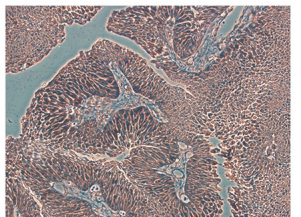

$(+++)$

B

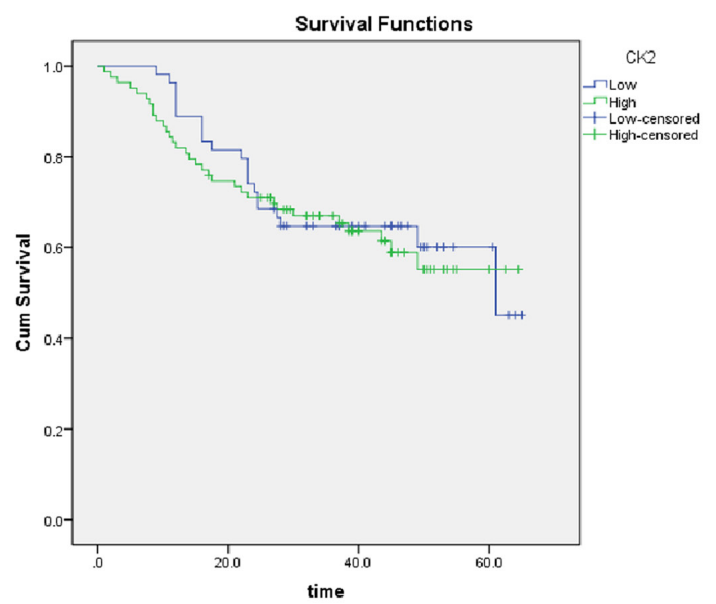

Figure 2: IHC analyses of CK2 $\alpha$ protein expression in primary BCa surgical specimens and Kaplan-Meier survival analyses of the primary BCa patients $(\boldsymbol{n}=\mathbf{1 3 7})$. A. CK2 $\alpha$ staining in BCa, scored as CK2 $\alpha(-)(+)(++)(++)$. All images are shown at $\times 100$ magnification and $\times 200$ magnification. B. BCa patients were divided into low-CK2 $\alpha$ expression $(n=54$, CK2 $\alpha-$ or CK2 $2 \alpha+)$ and high-CK2 $\alpha$ expression $(n=83$, CK2 $\alpha++$ or CK2 $\alpha+++)$ groups. Survival analyses did not reveal a significant association between high CK2 $\alpha$ expression and poor prognosis $(P=0.694, \log$-rank test $)$.

A

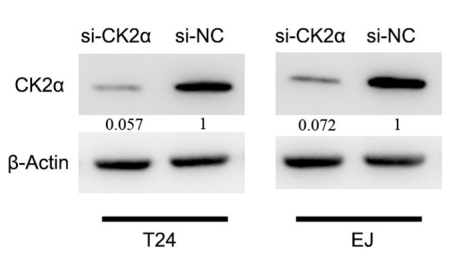

D

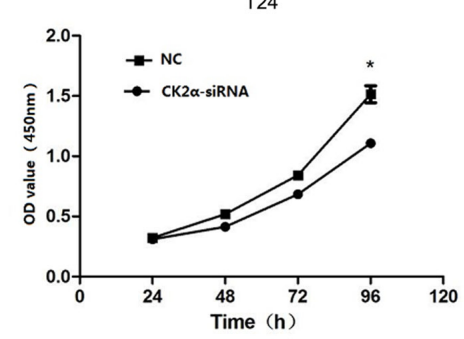

B

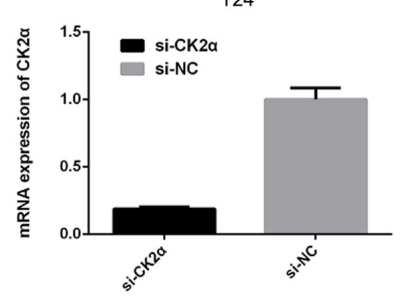

E
C

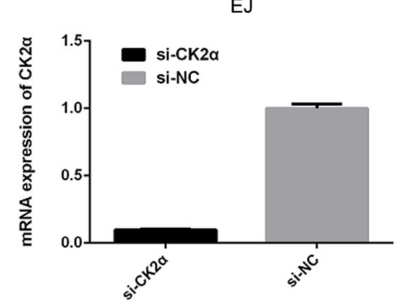

EJ

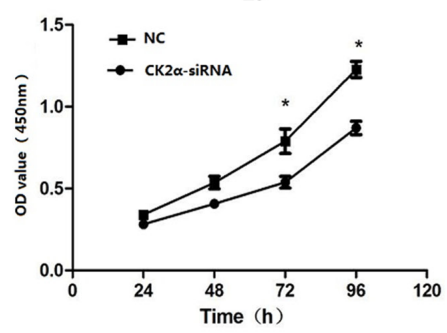

Figure 3: CK2 $\alpha$ was essential for bladder cancer cell proliferation. A, B, C. Knockdown efficiency of selected CK2 $\alpha$-targeting siRNAs in transfected cells was evaluated by Western blot and qRT-PCR. D, E. CCK 8 assay showed that silencing of CK2 $\alpha$ suppressed proliferation of T24 (D) and EJ (E) cell lines. 
5B). We found that treatment with CX-4945 significantly inhibited the migration ability in bladder cancer cells (Figure 5D; both $\mathrm{P}<0.05$ ). CX-4945 induced apoptosis in both cell lines (Figure 6; both $\mathrm{P}<0.05$ ). Thus, CK2 inhibition abrogated many biological functions of bladder cancer that are critical to tumor growth and survival.

\section{Knockdown of CK2 $\alpha$ inhibits the growth of tumor xenografts in nude mice}

We evaluated the effects of CK2 $\alpha$ Knockdown on tumor growth in vivo. The transfected EJ cells were implanted into the right axilla of the nude mouse by subcutaneous injection, and the tumor volumes were measured after injection. Compared with the control cells, the mean volumes of the xenograft
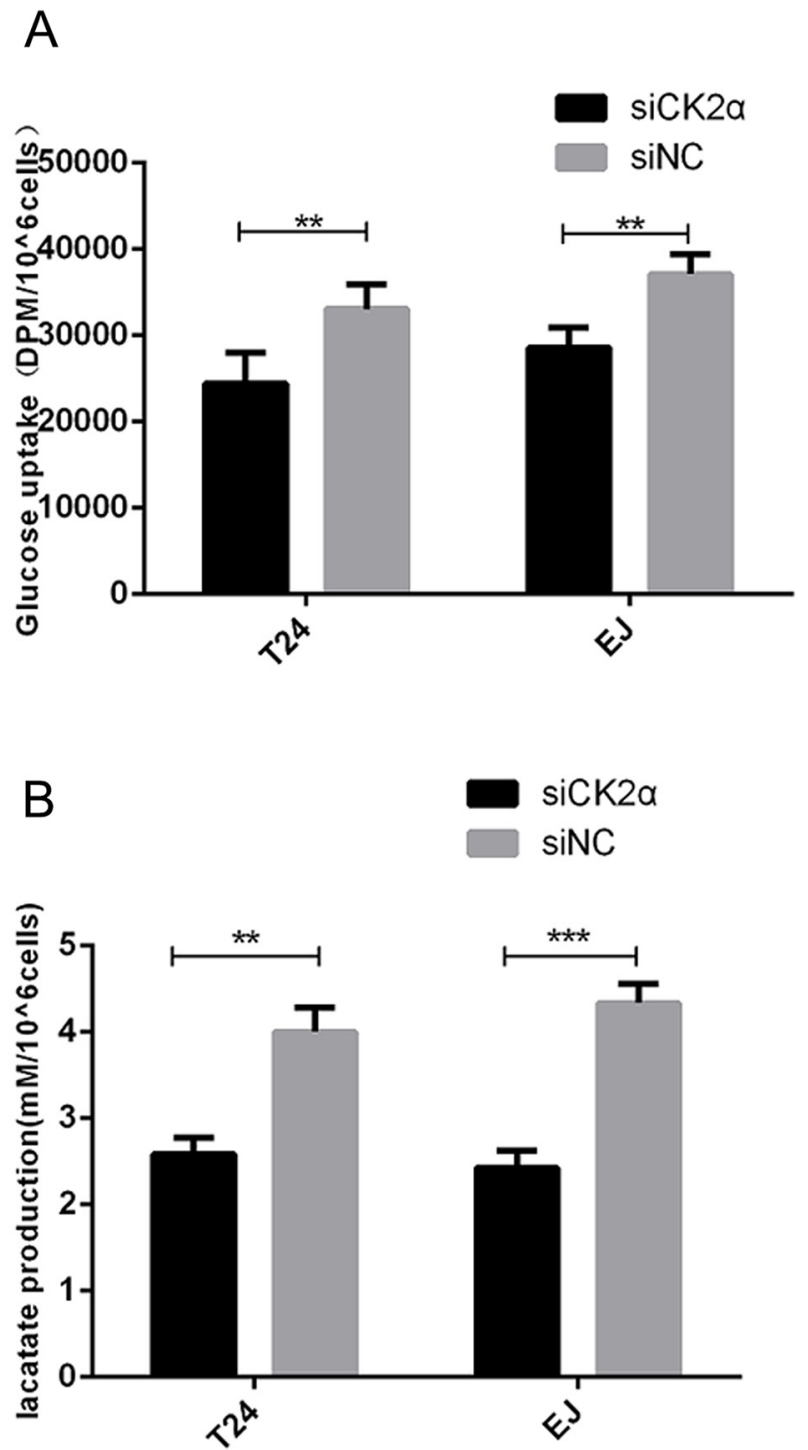

tumors treated with CK2 $\alpha$ knockdown cells showed obvious growth retardation (Figure 7A, 7B, 7C, 7D). Immunohistochemical staining identified that the level of CK $2 \alpha$ was inhibited in the CK $2 \alpha$ knockdown tumors (Figure 7E).

\section{DISCUSSION}

Protein kinase $\mathrm{CK} 2 \alpha$, one isoform of the catalytic subunit of serine/threonine protein kinase CK2, has been demonstrated to be overexpressed in various malignancies [26-28]. However, its underlying role in bladder cancer remains unclear.

In this study, we revealed that CK2 $\alpha$ was frequently and significantly upregulated in human bladder cancer. The level of CK2 $\alpha$ in bladder cancer cell lines except 5637

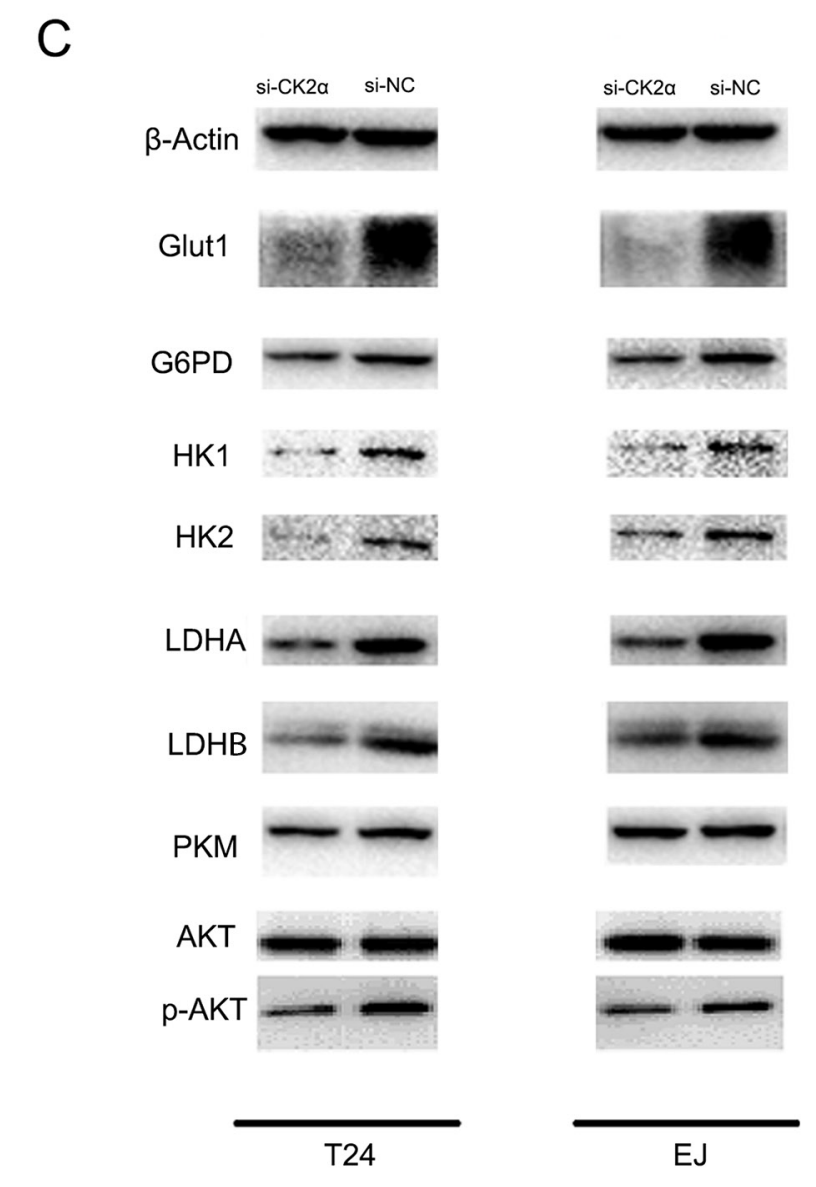

Figure 4: CK2 $\alpha$ inhibition induced a metabolic shift in bladder cancer cells. A. Glucose uptake assays. CK2 $\alpha$ inhibition decreased glucose uptake. B. Lactate production assays. CK2 $\alpha$ inhibition suppressed lactate secretion. C. CK2 $\alpha$ inhibition decreased protein expression in cancer aerobic glycolysis. 
was increased compared with that in the normal urinary epithelial cell line sv-Huc. The difference results might be caused by low malignance of 5637 or heterogeneity of tumor. We expect further research on this issue. IHC analyses convincingly demonstrated that $\mathrm{CK} 2 \alpha$ was overexpressed in primary bladder cancer. Increased expression of CK $2 \alpha$ was shown in $63.1 \%$ of BCa samples, and was significantly correlated with tumor grade. These findings indicated that $\mathrm{CK} 2 \alpha$ was an oncogene promoting bladder cancer progression and correlated with pathogenesis.
As a prognostic marker in various malignancies, CK2 $\alpha$ expression is positively correlated with histological grade, distant metastasis, tumor stage and outcome [15, 27, 29]. However, we found no significant evidence to identify the relationship between high CK2 $\alpha$ expression and tumor stage and prognosis. These differences might be attributed to tumor heterogeneity.

Numerous signaling pathways have been researched, through which CK2 regulates cancer cell survival, but the relationship between $\mathrm{CK} 2$ and glucose metabolism remains unknown. Our present work suggested that CK2
A

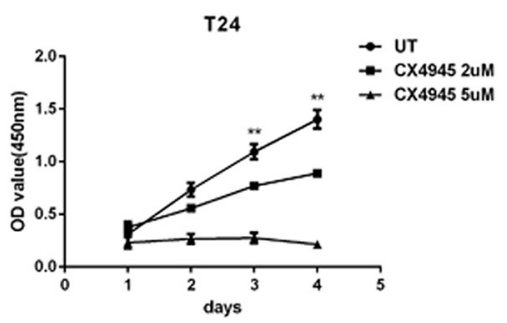

B

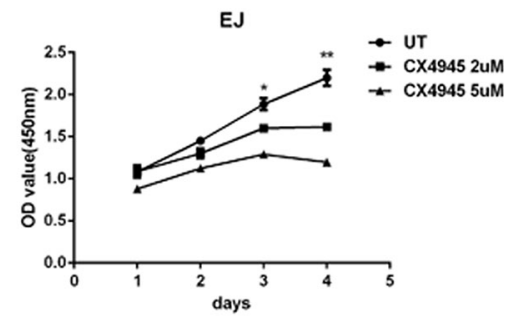

D-2

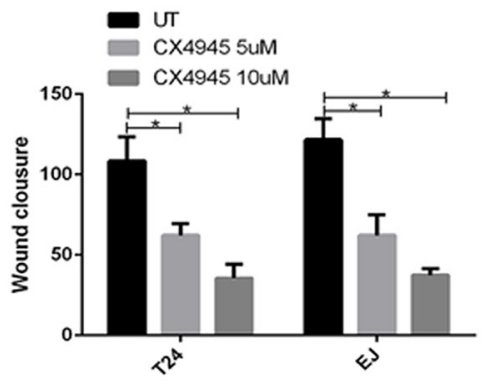

$\mathrm{C}$

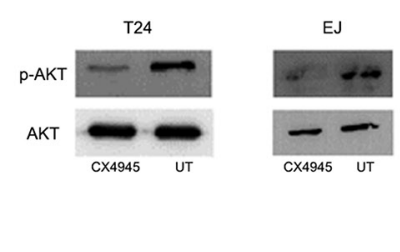

$E$

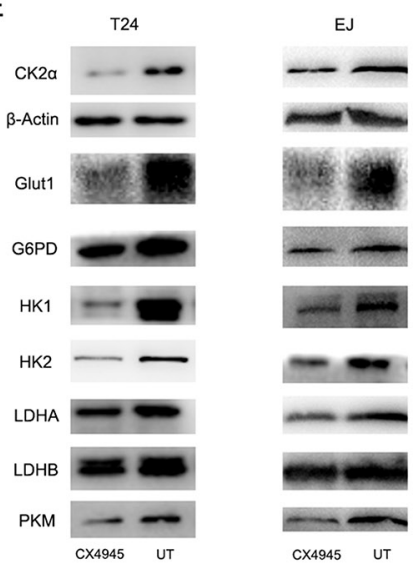

$\mathrm{F}$

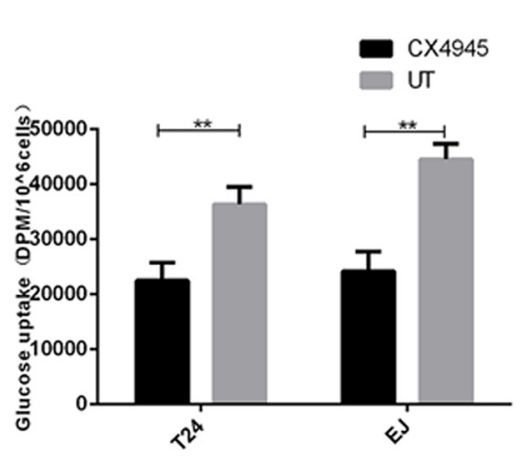

G

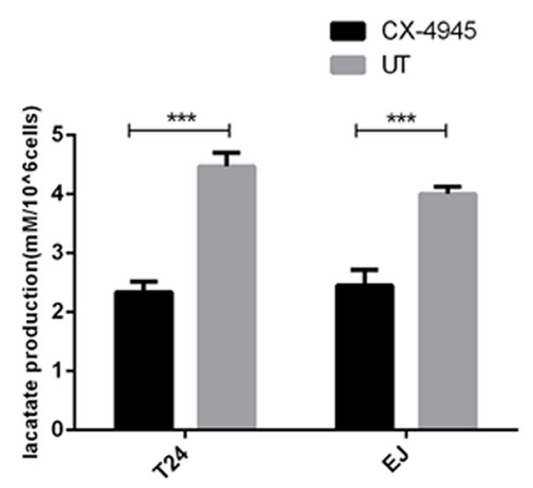

Figure 5: Effects of inhibition of CK2 on bladder cancer cell function. A, B. CX-4945 suppressed proliferation of T24 (A) and EJ (B) cell. C, E. Western blot analysis showed that protein expression in cancer aerobic glycolysis was downregulated in T24 and EJ cells after treatment with CX4945. AKT and p-AKT(ser473) (C). GLUT1, G6PD, HK1, HK2, LDHA, LDHB and PKM (E). D. CX-4945 inhibited the migration ability in T24 and EJ cell lines. F. Glucose uptake assays. CX-4945 decreased glucose uptake. G. Lactate production assays. CX-4945 suppressed lactate secretion. 
may be a positive regulator in cell survival via the glucose metabolic pathway in bladder cancer. Several lines of evidence support this finding. Firstly, the inhibition of CK $2 \alpha$ resulted in the downregulation of glycolysis-related protein level, as well as decrease in glucose uptake and lactate production. Secondly, suppressed cell proliferation was observed after CK2 $\alpha$ knockdown. Finally, similar results were reproduced after treatment with CX-4945 even with a dose-dependent response in both cell lines.

Our previous study demonstrated that the expression level of the glycolysis-related genes in bladder tumor tissues was frequently overexpressed compared with those in adjacent tissues [25]. Through the glucose metabolic pathway, tumor cells consume glucose to produce a large number of ATP, lactate, $\mathrm{NAD}+, \mathrm{NADPH}$, and $\mathrm{H}+$ cofactors, which are used for the growth and proliferation of cancer cells. In our study, we knocked down CK2 $\alpha$ level in bladder cancer cells and then observed decrease in glucose uptake and lactate production, accompanied with low level of GLUT1, HK, PKM, and LDH. These results suggested that CK2 $\alpha$ positively regulated the activation of glycolysis. Interestingly, $\mathrm{CK} 2 \alpha$ silencing reduced the expression level of G6PD, which was of great importance for the pentose phosphate pathway (PPP). PPP is a key source of NADPH, as a cofactor in maintaining the redox balance and for anabolic pathways, such as fatty acid biosynthesis [30]. Moreover, PPP produces ribose and is involved in the transcription of gene expression during stress conditions [31].

In human glioblastoma, CK2 suppresses apoptosis and promotes oncogenes via enhancing the AKT pathways and downstream gene expression [18]. Consistent with these observations, AKT was found to be less phosphorylated in $\mathrm{CK} 2 \alpha$ knockdown cells than in control cells, which suggested that CK2 $\alpha$-regulated glycolysis was related to the AKT pathway. Several reports conveyed the ability of CK2 inhibitors to suppress the PI3K-AKT-mTOR pathway [32-34]. Dr. Ruzzenne demonstrated that CK2 phosphorylates AKT directly at Ser129, further increasing the catalytic activity of AKT [35]. Unsurprisingly, hyper activation of PI3K-AKTmTOR signaling was shown to be a consequence of CK2 overexpression [36, 37]. Researchers have found that the PI3K-AKT-mTOR axis was an essential pathway for various cellular processes, including glycolysis [38, 39]. Moreover, AKT has been reported to function as a master regulator of energy metabolism in cancer cells by enhancing the expression of glycolytic regulators [38]. Taken together, CK2 $\alpha$ inhibition may suppress high glycolysis level via the CK2 $\alpha /$ AKT-mTOR cascade in bladder cancer cells.
A

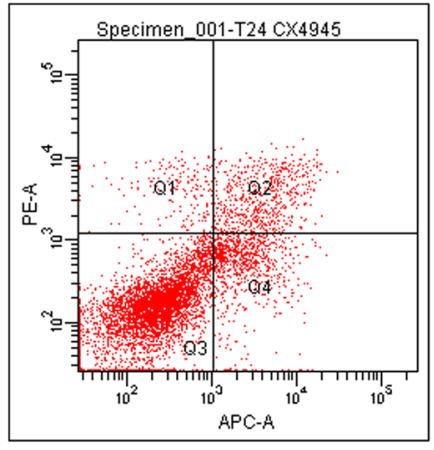

B

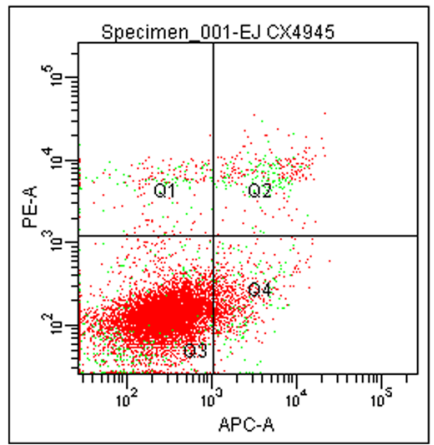

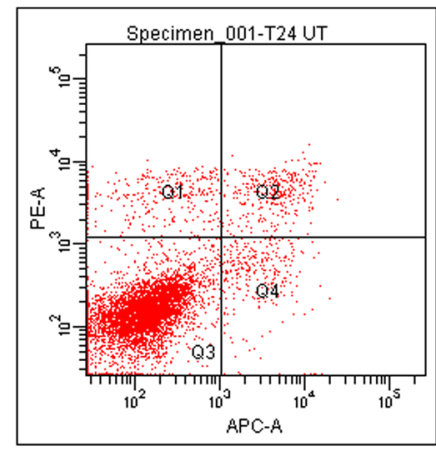
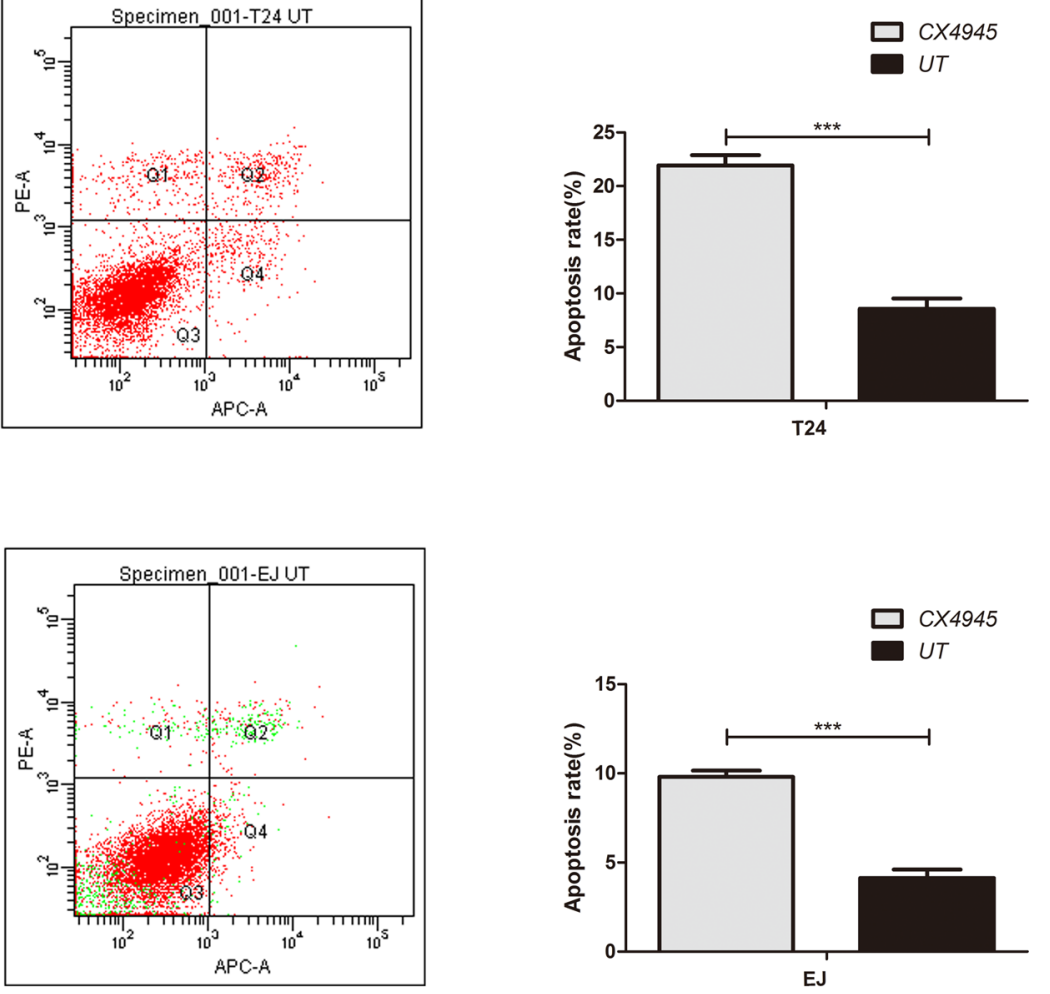

Figure 6: Effect of inhibition of CK2 on apoptosis in bladder cancer cells. CX-4945 induced apoptosis in T24(A) and EJ(B) cell lines. 
Notably, bladder cancer cell treatment with CX4945 strongly inhibited activation of AKT phosphorylation and glycometabolism. After treatment with CX-4945, it were observed that suppressed cell proliferation and cell migration and induced cell apoptosis. Thus, CK2 inhibitors, such as CX-4945, may provide a potential therapeutic target for patients with bladder cancer. Moreover, in vivo xenograft study showed that knockdown of CK $2 \alpha$ decreased the tumorigenicity of bladder cancer cells.
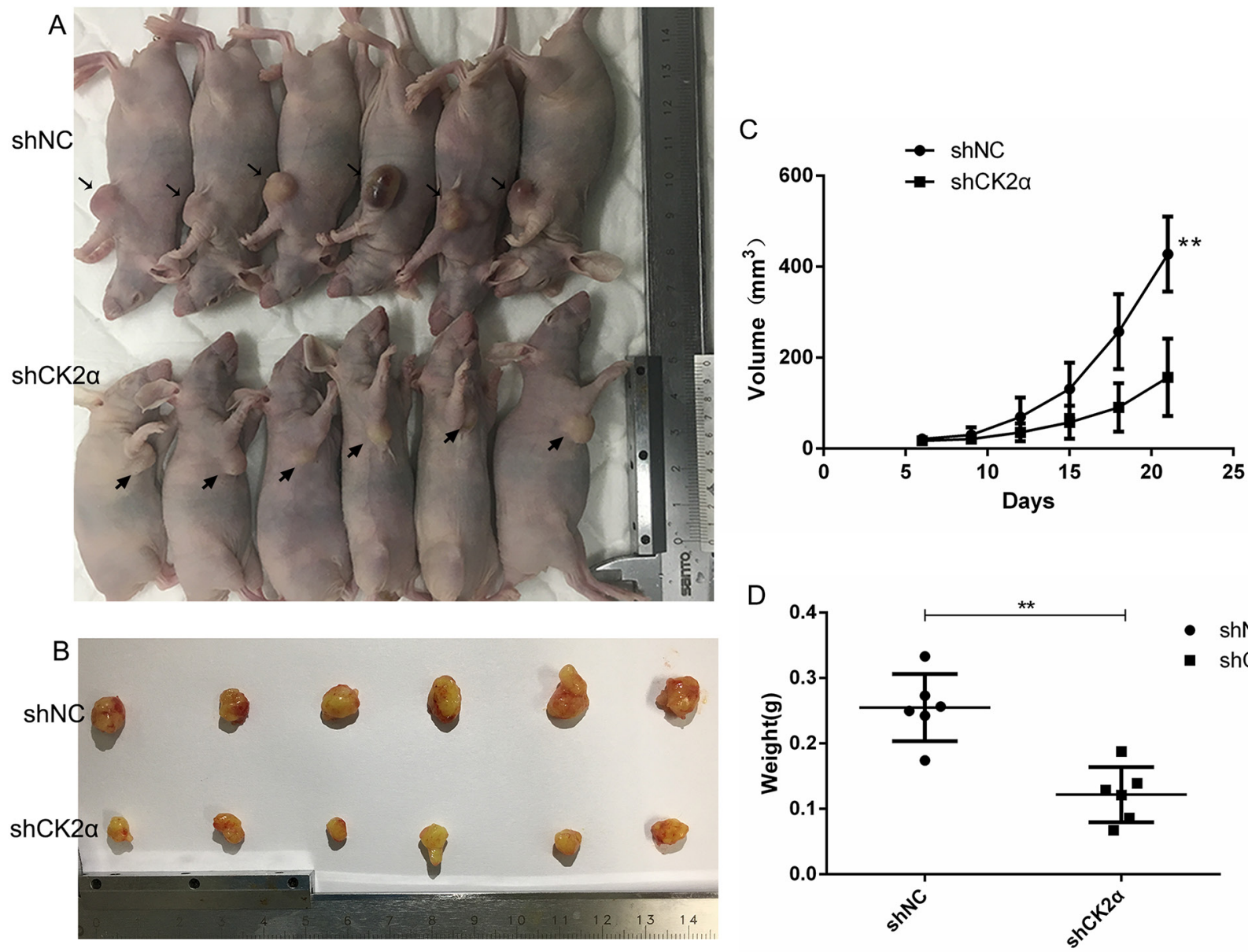

E

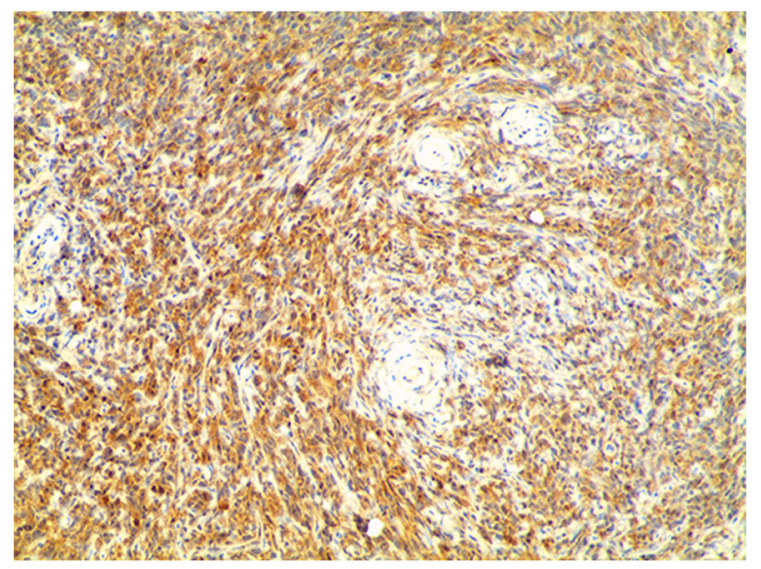

shNC

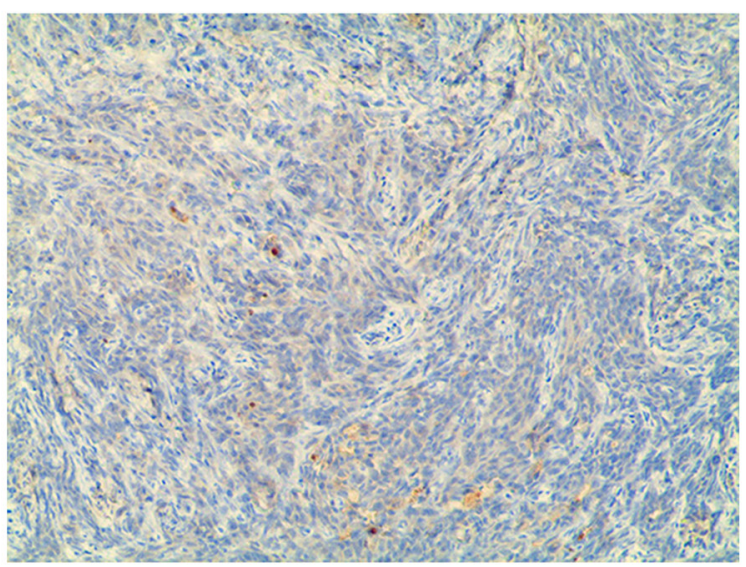

shCK2 $\alpha$

Figure 7: CK2 $\alpha$ inhibition decreased tumorigenesis and reduced cancer cell growth in vivo. A, B. CK2 $\alpha$ knockdown EJ cells formed smaller tumour volume compared to the control cells $(\mathrm{NC})$. C. The tumor growth curves in the two groups $(P<0.01)$. D. CK2 $\alpha$ knockdown reduced tumor weight compared to the control cells $(\mathrm{NC})(P<0.01)$. E. CK2 $\alpha$ immunohistochemistry staining of xenografted tumors retrieved from treated nude mice. Representative images are shown. (magnification, $\times 100$ ) 


\section{MATERIALS AND METHODS}

\section{Clinical specimens and cell culture}

Bladder cancer and adjacent non-tumor tissues were obtained from patients undergoing radical cystectomy at the First Affiliated Hospital of Nanjing Medical University. All patients provided signed informed consent, and the Research Ethics Committee of our institution approved this study. The specimens were immediately frozen and stored in liquid nitrogen. Pathological examination was performed to confirm cancer diagnosis.

Bladder cancer cell lines T24 and EJ were obtained from the Type Culture Collection of the Chinese Academy of Sciences (Shanghai, China). Cells were cultured in RPMI 1640 medium supplemented with $10 \%$ fetal bovine serum (FBS; Gibco, Australia) and 1\% penicillinstreptomycin in an incubator with humidified $5 \% \mathrm{CO}_{2}$ at $37^{\circ} \mathrm{C}$.

All the bladder cancer specimens we used in our work are urothelial carcinomas. The cell type of T24, J82, EJ, 5637, 253J and TCC is Transitional Cell Carcinoma, while the cell type of RT4 is Transitional Cell Papilloma.

\section{Tissue microarray (TMA) and Immunohistochemistry (IHC)}

TMA $(16 \times 10)$ was constructed from 160 cases of bladder tumor tissues. TMAs were kept at $4{ }^{\circ} \mathrm{C}$ until they were ready for analysis.

Sections were arranged in duplicate cores per case. TMAs were treated with xylene and $100 \%$ ethanol, followed by decreased concentrations of ethanol. After antigen retrieval, TMAs were blocked and stained with antibodies against CK2 $\alpha$, followed by secondary antibody incubation and standard avidin biotinylated peroxidase complex method. Hematoxylin was used for counterstaining, and images were obtained with an upright microscope system (Nikon, JAPAN).

The total CK2 $\alpha$ immunostaining score was calculated as the sum of the score for the proportion of positively stained tumor cells and the score for staining intensity given by two pathologists blinded to the clinical parameters. The proportion of positively stained tumor cells was scored as follows: "0" ( $<5 \%$, negative), " 1 " (5\%-25\%, sporadic), " 2 " $(25 \%-50 \%$, focal $)$, and " 3 " $(>50 \%$, diffuse). The intensity of staining was graded according to the following criteria: " 0 " (no staining), "1" (weak staining = light yellow), " 2 " (moderate staining = yellow brown), and "3" (strong staining = brown). The total immunostaining score, which ranged from 0 to 9 , was calculated as the value of the proportion of positive cell score $\times$ staining intensity score. The expression level of CK2 $\alpha$ was defined as follows: "-" (negative, score 0), "+" (weakly positive, score 1-3), "++" (positive, score 4-6), or "+++" (strong positive, score 7-9). Thus, CK2 $\alpha$ protein expression in $\mathrm{BCa}$ specimens was divided into two groups: low CK2 $\alpha$ expression group (CK2 $2 \alpha^{\prime \prime-}$ " or CK $2 \alpha^{\prime \prime+}+$ ") and high CK2 $\alpha$ expression group (CK2 $\left.2 \alpha^{\prime \prime++" ~ o r ~ C K ~} 2 \alpha “+++"\right)$ (Figure 2A).

\section{CK2 $\alpha$ inhibitor}

CK2 $\alpha$ siRNA and control siRNA were purchased from Shanghai GenePharma Co., Ltd. Cells were seeded in a six-well plate at $10^{\wedge 5}$ cells/well 1 day before transfection, with a target of $30 \%-50 \%$ confluence at the time of transfection. Cells were transfected with $50 \mathrm{nmol} / \mathrm{L}$ siRNA using Lipofectamine RNAiMAX (Invitrogen) according to the manufacturer's protocol. Adequate inhibition of siRNA-mediated knockdown was confirmed by Western blot. The pcDNA3.1- CK2 $\alpha$ or control pcDNA3.1-LacZ plasmid vectors were then transfected into T24 and EJ cells $(0.51 \mathrm{~g} / \mathrm{mL}$ in a 24 -well plate) using Lipofectamine 2000 transfection reagent (Invitrogen), according to the manufacturer's protocol. Cells were harvested for qRTPCR and Western blot or used in other assays at $48 \mathrm{~h}$ posttransfection.

Lentivirus constructs were generated to knockdown CK2 $\alpha$. The bladder cancer cell EJ was stably transfected with LV3pGLV-h1-GFP-puro negative control vectors (termed as shNC) and CK2 $\alpha$ knockdown lentivirus (termed as shCK2 $\alpha$ ), following the manufacturer's instructions (Abm, Nanjing, China). Lentiviral constructs of CK2 $\alpha$ knockdown were generated as previously described. Cells were plated in 6 wells dishes at $40 \%$ confluence and infected with the retroviruses. Meanwhile, polybrene ( $3 \mu \mathrm{g} / \mathrm{ml}$ ) was added with the retroviruses to enhance infection efficiency. Stable pooled populations of bladder cancer cells were generated by selection using puromycin $(3 \mu \mathrm{g} / \mathrm{ml})$ for 3 weeks. For CK2 $\alpha$ knockdown cells, which achieved $\geq 75 \%$ knockdown efficiency of mRNA was used for further studies.

CX-4945(small-molecule CK2 inhibitor) was purchased from Selleckchem.

\section{RNA extraction and quantitative RT-PCR}

Total RNA from 44 frozen bladder tissues (22 for tumor tissues and 22 for paired adjacent normal tissues) and bladder cancer cells was extracted by Trizol according to the manufacturer's instructions. cDNA was prepared from $1 \mu \mathrm{g}$ of total RNA in a $30 \mu \mathrm{L}$ volume using PrimeScript ${ }^{\mathrm{TM}}$ RT Master Mix (Takara Bio, Dalian, China). The reaction mixture was incubated at $37^{\circ} \mathrm{C}$ for $15 \mathrm{~min}, 85^{\circ} \mathrm{C}$ for $5 \mathrm{~s}$, and $4^{\circ} \mathrm{C}$ for $5 \mathrm{~min}$. The synthesized cDNA was used for PCR amplification or stored at $-20^{\circ} \mathrm{C}$ for further analysis.

The PCR reaction was performed in a $25 \mu \mathrm{L}$ volume containing $0.25 \mathrm{mM}$ of each dNTP, $1 \mathrm{U}$ HotstarTaq (Takara), and $0.5 \mathrm{mM}$ of each primer (Takara): 5'-CCGAGTTGCTTCCCGATAC-3' (forward) and 
5'-GGGCTGACAAGGTGCTGAT-3' (reverse) for CK2 $\alpha$; 5'-AGCGAGCATCCCCCAAAGTT-3' (forward) and 5'-GGGCACGAAGGCTCATCATT' (reverse) for $\beta$-actin.

\section{Western blot analysis}

Cells were lysed, and the protein was extracted using RIPA buffer (Beyotime, China) and quantified by a BCA Protein Assay Kit (Beyotime, China). Equivalent quantities of protein were separated on $10 \%$ SDS-PAGE gels and transferred to polyvinylidene fluoride membranes. After blocking with 5\% nonfat milk at room temperature for $1 \mathrm{~h}$, the membranes were immunostained with primary antibodies at $4{ }^{\circ} \mathrm{C}$ overnight, washed three times in TBST, and incubated with secondary antibody at room temperature for $1 \mathrm{~h}$. Band signals were detected using a chemiluminescence system (Bio-Rad, USA) and analyzed using Image Lab Software. The following primary antibodies were used: primary antibodies against GLUT1, LDHA, LDHB, G6PD, 6PGD, and PKM2 were obtained from Epitomics, whereas those against HK1, HK2, AKT, and phospho-AKT(Ser473) were obtained from Cell Signaling Technology. CK2 $\alpha$ was obtained from Millipore. The protein levels were normalized to $\beta$-actin (1:1000, Cell Signaling Technology).

\section{Measurement of glucose uptake}

For glucose uptake experiments, cells were plated in six-well plates at a density of $3 \times 10^{5}$ cells/well at 24 $\mathrm{h}$ before the experiment was performed. Cells were then washed with PBS, and uptake was initiated by incubating cells in $2 \mathrm{~mL}$ of Krebs-Ringer-HEPES (KRH) buffer (25 mMHepes, pH 7.4, $120 \mathrm{mMNaCl}, 5 \mathrm{mMKCl}, 1.2 \mathrm{mM}$ $\mathrm{MgSO}_{4}, 1.3 \mathrm{mM} \mathrm{CaCl}_{2}$, and $1.3 \mathrm{mM} \mathrm{KH}_{2} \mathrm{PO}_{4}$ ) containing 1 $\mu \mathrm{Ci}$ of [3H]-2-deoxyglucose (PerkinElmer Life Sciences) for $20 \mathrm{~min}$. Uptake was stopped by washing the cells with ice-cold KRH buffer. Cells were dissolved in $300 \mu \mathrm{L}$ of lysis buffer (10 mMTris-HCl, pH 8.0, 0.2\% SDS). Liquid scintillation spectrometry was performed to determine the radioactivity level of each aliquot. Disintegrations per minute value was used to evaluate the intracellular level of [3H]-2-deoxyglucose, and each assay was performed in triplicate.

\section{Measurement of extracellular lactate}

Approximately $3 \times 10^{5}$ cells/well were seeded into six-well plates that were incubated in $2 \mathrm{~mL}$ of RPMI 1640 with $10 \%$ FBS. After incubation for $24 \mathrm{~h}$, the supernatant was collected. The lactate concentration in the supernatant was quantified by performing a fluorescence-based assay according to the manufacturer's instructions (L-Lactate Assay Kit, Cayman). The lactate concentration in the supernatant without seeded cells was also calculated and used to eliminate the effect of lactate on RPMI 1640 medium. Each assay was performed in triplicate.

\section{Cell viability assay}

For cell viability assay, the transfected cells were seeded into 96-well plates at a density of 3000 cells/well. The CCK8 method was used to determine cell viability at $24,48,72$, and $96 \mathrm{~h}$ after the cells were seeded. The absorbance was measured at $450 \mathrm{~nm}$ using a Tecan Infinite F200 microplate reader.

\section{Wound healing assay}

Cells were seeded into six-well plates and cultured until they reached $95 \%$ confluence. A $200 \mu \mathrm{L}$ pipette tip was used to generate a cross-shaped wound through the center of the well. The cultures were washed with PBS to remove cell debris, and the cells were incubated in RPMI 1640 medium without FBS. The wound was observed under a microscope (Olympus, Japan) at $40 \times$ magnification at two preselected time points ( 0 and $36 \mathrm{~h})$, and the widths of wounds were counted.

\section{Apoptosis assay}

After treatment with CX-4945 for $12 \mathrm{~h}$, cells were trypsinized, stained with Annexin $\mathrm{V}$ and propidium iodide, and examined by flow cytometry.

\section{In vivo tumor xenograft studies}

BALB/C female nude mice (4-6-weeks old, 18-22 g) were randomly divided into two groups (each containing 6 mice). The transfected EJ cells and controls were implanted with $1 \times 10^{7}$ cells in $0.1 \mathrm{ml}$ PBS per site on the axilla in nude mice $(n=6)$. Tumor growth was monitored by measuring the width $(\mathrm{W})$ and length $(\mathrm{L})$ with calipers every 3 days, and the volume $(\mathrm{V})$ of the tumor was calculated using the formula $\mathrm{V}=\left(\mathrm{W}^{2} \times \mathrm{L}\right) / 2$. After 21 days, mice were sacrificed and checked for final tumor size. At the end of the experiment, the tumors were removed and fixed in $4 \%$ formalin for immunohistochemical analysis. The animal studies were performed in accordance with the institutional ethics guidelines for animal experiments.

\section{Statistical analysis}

Statistical analysis was performed using SPSS 20.0 and GraphPad Prism 5. All data are presented as the mean \pm standard deviation. Differences between two groups were analyzed using Student's $t$-test. Cell viability assay and in vivo tumor xenograft results were assessed by repeated measures ANOVA. $\mathrm{P}<0.05$ was considered statistically significant. All experiments were repeated more than three times, and each experiment was performed in triplicate. 


\section{CONCLUSIONS}

Our study revealed the relationship between CK2 $\alpha$ overexpression and unfavorable progression in bladder cancer patients. For the first time, we reported that targeting CK2 suppressed bladder cancer cell survival via downregulation of AKT-mTOR and the glucose metabolic pathway in urinary bladder cancer. However, the precise mechanism needs to be elucidated. Our results could be regarded as the basis for a candidate prognostic biomarker and new potential therapeutic strategies for bladder cancer. Our study also provided new insights into the regulation of glycolysis by protein kinase CK2.

\section{ACKNOWLEDGMENTS AND FUNDING}

This work was supported by grants from the National Natural Science Foundation of China (Grant Nos. 81272832 and 81602235) and Innovation Project for Postgraduate of Jiangsu Province (KYLX16-1110).

\section{CONFLICTS OF INTEREST}

The authors declare that no competing interests exist.

\section{REFERENCES}

1. Torre LA, Bray F, Siegel RL, Ferlay J, Lortet-Tieulent J and Jemal A. Global cancer statistics, 2012. Cancer J Clin. 2015; 65:87-108.

2. Burnett $G$ and Kennedy EP. The enzymatic phosphorylation of proteins. The Journal of biological chemistry. 1954; 211:969-980.

3. Litchfield DW. Protein kinase CK2: structure, regulation and role in cellular decisions of life and death. Biochem $\mathrm{J}$. 2003; 369:1-15.

4. Trembley JH, Wang G, Unger G, Slaton J and Ahmed K. Protein kinase CK2 in health and disease: CK2: a key player in cancer biology. Cell Mol Life Sci. 2009; 66:1858-1867.

5. Duncan JS and Litchfield DW. Too much of a good thing: the role of protein kinase CK2 in tumorigenesis and prospects for therapeutic inhibition of CK2. Biochim Biophys Acta. 2008; 1784:33-47.

6. Dominguez I, Sonenshein GE and Seldin DC. Protein kinase CK2 in health and disease: CK2 and its role in Wnt and NF-kappaB signaling: linking development and cancer. Cell Mol Life Sci. 2009; 66:1850-1857.

7. Guerra B. Protein kinase CK2 subunits are positive regulators of AKT kinase. Int J Oncol. 2006; 28:685-693.

8. Zhang S, Long H, Yang YL, Wang Y, Hsieh D, Li W, Au A, Stoppler HJ, Xu Z, Jablons DM and You L. Inhibition of CK2alpha down-regulates Notch1 signalling in lung cancer cells. J Cell Mol Med. 2013; 17:854-862.
9. Zhang S, Yang YL, Wang Y, You B, Dai Y, Chan G, Hsieh D, Kim IJ, Fang LT, Au A, Stoppler HJ, Xu Z, Jablons DM and You L. CK2alpha, over-expressed in human malignant pleural mesothelioma, regulates the Hedgehog signaling pathway in mesothelioma cells. J Exp Clin Cancer Res. 2014; 33:93.

10. Romieu-Mourez R, Landesman-Bollag E, Seldin DC, Traish AM, Mercurio F and Sonenshein GE. Roles of IKK kinases and protein kinase CK2 in activation of nuclear factor-kappaB in breast cancer. Cancer research. 2001; 61:3810-3818

11. Laramas M, Pasquier D, Filhol O, Ringeisen F, Descotes $\mathrm{JL}$ and Cochet C. Nuclear localization of protein kinase CK2 catalytic subunit (CK2alpha) is associated with poor prognostic factors in human prostate cancer. Eur J Cancer. 2007; 43:928-934.

12. Daya-Makin M, Sanghera JS, Mogentale TL, Lipp M, Parchomchuk J, Hogg JC and Pelech SL. Activation of a tumor-associated protein kinase (p40TAK) and casein kinase 2 in human squamous cell carcinomas and adenocarcinomas of the lung. Cancer research. 1994; 54:2262-2268.

13. So KS, Rho JK, Choi YJ, Kim SY, Choi CM, Chun YJ and Lee JC. AKT/mTOR down-regulation by CX-4945, a CK2 inhibitor, promotes apoptosis in chemorefractory non-small cell lung cancer cells. Anticancer Res. 2015; 35:1537-1542.

14. Faust RA, Gapany M, Tristani P, Davis A, Adams GL and Ahmed K. Elevated protein kinase CK2 activity in chromatin of head and neck tumors: association with malignant transformation. Cancer Lett. 1996; 101:31-35.

15. Lin KY, Tai C, Hsu JC, Li CF, Fang CL, Lai HC, Hseu $\mathrm{YC}$, Lin YF and Uen YH. Overexpression of nuclear protein kinase CK2 alpha catalytic subunit (CK2alpha) as a poor prognosticator in human colorectal cancer. PLoS One. 2011; 6:e17193.

16. Lin KY, Fang CL, Chen Y, Li CF, Chen SH, Kuo CY, Tai C and Uen YH. Overexpression of nuclear protein kinase CK2 Beta subunit and prognosis in human gastric carcinoma. Ann Surg Oncol. 2010; 17:1695-1702.

17. Stalter G, Siemer S, Becht E, Ziegler M, Remberger K and Issinger OG. Asymmetric expression of protein kinase CK2 subunits in human kidney tumors. Biochem Biophys Res Commun. 1994; 202:141-147.

18. Zheng Y, McFarland BC, Drygin D, Yu H, Bellis SL, Kim H, Bredel M and Benveniste EN. Targeting protein kinase CK2 suppresses prosurvival signaling pathways and growth of glioblastoma. Clinical cancer research. 2013; 19:6484-6494.

19. Siddiqui-Jain A, Drygin D, Streiner N, Chua P, Pierre F, O'Brien SE, Bliesath J, Omori M, Huser N, Ho C, Proffitt C, Schwaebe MK, Ryckman DM, Rice WG and Anderes K. CX-4945, an orally bioavailable selective inhibitor of protein kinase CK2, inhibits prosurvival and angiogenic signaling and exhibits antitumor efficacy. Cancer research. 2010; 70:10288-10298. 
20. Pierre F, Chua PC, O'Brien SE, Siddiqui-Jain A, Bourbon P, Haddach M, Michaux J, Nagasawa J, Schwaebe MK, Stefan E, Vialettes A, Whitten JP, Chen TK, Darjania L, Stansfield R, Bliesath J, et al. Pre-clinical characterization of CX-4945, a potent and selective small molecule inhibitor of CK2 for the treatment of cancer. Mol Cell Biochem. 2011; 356:37-43.

21. Hinkle $\mathrm{PC}$. $\mathrm{P} / \mathrm{O}$ ratios of mitochondrial oxidative phosphorylation. Biochim Biophys Acta. 2005; 1706:1-11.

22. Warburg O. On the origin of cancer cells. Science. 1956; 123:309-314.

23. Cairns RA, Harris IS and Mak TW. Regulation of cancer cell metabolism. Nat Rev Cancer. 2011; 11:85-95.

24. Kroemer $\mathrm{G}$ and Pouyssegur J. Tumor cell metabolism: cancer's Achilles' heel. Cancer Cell. 2008; 13:472-482.

25. Yang X, Cheng Y, Li P, Tao J, Deng X, Zhang X, Gu $\mathrm{M}, \mathrm{Lu} \mathrm{Q}$ and Yin C. A lentiviral sponge for miRNA-21 diminishes aerobic glycolysis in bladder cancer T24 cells via the PTEN/PI3K/AKT/mTOR axis. Tumour Biol. 2015; 36:383-391.

26. Zhang S, Wang Y, Mao JH, Hsieh D, Kim IJ, Hu LM, $\mathrm{Xu} \mathrm{Z}$, Long $\mathrm{H}$, Jablons DM and You L. Inhibition of CK2alpha down-regulates Hedgehog/Gli signaling leading to a reduction of a stem-like side population in human lung cancer cells. PLoS One. 2012; 7:e38996.

27. Zou J, Luo H, Zeng Q, Dong Z, Wu D and Liu L. Protein kinase CK2alpha is overexpressed in colorectal cancer and modulates cell proliferation and invasion via regulating EMT-related genes. J Transl Med. 2011; 9:97.

28. Kim HS, Chang YG, Bae HJ, Eun JW, Shen Q, Park SJ, Shin WC, Lee EK, Park S, Ahn YM, Park WS, Lee JY and Nam SW. Oncogenic potential of CK2alpha and its regulatory role in EGF-induced HDAC2 expression in human liver cancer. FEBS J. 2014; 281:851-861.

29. Zhang HX, Jiang SS, Zhang XF, Zhou ZQ, Pan QZ, Chen CL, Zhao JJ, Tang Y, Xia JC and Weng DS. Protein kinase CK2alpha catalytic subunit is overexpressed and serves as an unfavorable prognostic marker in primary hepatocellular carcinoma. Oncotarget. 2015; 6:34800-34817. doi: 10.18632/oncotarget.5470.
30. Ying W. NAD+/NADH and NADP+/NADPH in cellular functions and cell death: regulation and biological consequences. Antioxid Redox Signal. 2008; 10:179-206.

31. Kruger A, Gruning NM, Wamelink MM, Kerick M, Kirpy A, Parkhomchuk D, Bluemlein K, Schweiger MR, Soldatov A, Lehrach H, Jakobs C and Ralser M. The pentose phosphate pathway is a metabolic redox sensor and regulates transcription during the antioxidant response. Antioxid Redox Signal. 2011; 15:311-324.

32. Kim JS, Eom JI, Cheong JW, Choi AJ, Lee JK, Yang WI and Min YH. Protein kinase CK2alpha as an unfavorable prognostic marker and novel therapeutic target in acute myeloid leukemia. Clinical cancer research. 2007; 13:1019-1028.

33. Olsen BB, Bjorling-Poulsen M and Guerra B. Emodin negatively affects the phosphoinositide 3-kinase/AKT signalling pathway: a study on its mechanism of action. Int J Biochem Cell Biol. 2007; 39:227-237.

34. Xagorari A, Roussos $\mathrm{C}$ and Papapetropoulos A. Inhibition of LPS-stimulated pathways in macrophages by the flavonoid luteolin. Br J Pharmacol. 2002; 136:1058-1064.

35. Di Maira G, Salvi M, Arrigoni G, Marin O, Sarno S, Brustolon F, Pinna LA and Ruzzene M. Protein kinase CK2 phosphorylates and upregulates Akt/PKB. Cell Death Differ. 2005; 12:668-677.

36. Silva A, Yunes JA, Cardoso BA, Martins LR, Jotta PY, Abecasis M, Nowill AE, Leslie NR, Cardoso AA and Barata JT. PTEN posttranslational inactivation and hyperactivation of the PI3K/Akt pathway sustain primary T cell leukemia viability. J Clin Invest. 2008; 118:3762-3774.

37. Panasyuk G, Nemazanyy I, Zhyvoloup A, Bretner M, Litchfield DW, Filonenko V and Gout IT. Nuclear export of S6K1 II is regulated by protein kinase CK2 phosphorylation at Ser-17. The Journal of biological chemistry. 2006; 281:31188-31201.

38. Robey RB and Hay N. Is Akt the "Warburg kinase"?-Aktenergy metabolism interactions and oncogenesis. Semin Cancer Biol. 2009; 19:25-31.

39. Wullschleger $\mathrm{S}$, Loewith $\mathrm{R}$ and Hall MN. TOR signaling in growth and metabolism. Cell. 2006; 124:471-484. 